\title{
The Influence on the Technical Ability and the Outcome of Development of New Technology through its Intermediate R\&D Group around IT Enterprises
}

\author{
LiHua Cui ${ }^{1}$, HyeJeong $\mathrm{Kim}^{2}$ and ${\mathrm{De} \mathrm{Li}^{3}}^{3}$ \\ ${ }^{1}$ College of Economics and Management, Yanbian University, Yanji, China \\ ${ }^{2}$ Department of School of Business Administration, Kyonggi University, Seoul, Korea \\ ${ }^{3}$ Department of Computer Science, Yanbian University, Yanji, China \\ ${ }^{1}$ 2732677@163.com, ${ }^{2}$ hj5417@naver.com, ${ }^{3}$ leader1223@ybu.edu.cn \\ *Corresponding author: HyeJeong Kim
}

\begin{abstract}
In this study, it is supposed, when utilizing the IT, that the $R \& D$ activation of intermediate groups can be a role of relational property. The active activation of intermediate groups plays a role of communicative mechanism, and it comes to be based upon the parts designing from its earlier steps and cooperative trust. It is mainly purposed to enhance such abilities as clearing the fund raising from outside, supplying through the related business partners, strategic partnership, and resolving the problems through the in-house human resources.

It is purposed to figure out the factors influencing on the enterprises' $R \& D$ and to understand their technical gap between small companies and conglomerates. To do this, it is conducted around the network theory which is combined with the resource dependent theory as the methodology for technique collaboration, at the same time looking at the importance of intermediate $R \& D$ organizations and problems from the environment inside and outside.
\end{abstract}

Keywords: Resources technical competence, Financial resources (Source of internal technology), Technical capacity, Development of new technologies performance, (External technology sources) Relationship Capital, (External technology sources) Relationship assets

\section{Introduction}

The R\&D of businesses are conducted around conglomerates, and it is not easy for the small companies to afford its development costs and risks. It is mostly caused by the fact that small companies, comparing to the conglomerates, more suffer from the mature lack of capitals, researchers, facilities, techniques, and administrative environment. To solve this problem, it could be more effective to make $\mathrm{R} \& \mathrm{D}$ activations of colleges and laboratories connect to those small companies through cooperative institutes operated by the government instead of supporting for the R\&D owned by the single company. In this case, those small companies can utilize the resources including researchers and utilities, as well as accessing to the results from colleges and laboratories. In case of the overseas, to support the R\&D activities of small companies, network business is more being expanded. But our intermediate $\mathrm{R} \& \mathrm{D}$ organization is still naive, and even the degree of recognition and participation is low. So even we have a lot of cooperation, associations, and groups which belong to the intermediate group, but it seems these have not enough ability to play the role of technique innovation. So it is necessary aggressively to encourage such activations and formation of systematic cooperated network. 


\section{Theoretical Backgrounds}

The assumption in this study is based upon the previous reports that the people having the IT knowledge can be recognized as the IT source (Mata et al., 1995, Bharadwaj, 2000, Ross et al., 1996), so they can lead to the new innovation ahead of the competitors (Sambamurthy and Zmud; 1997), and also the collaborations among enterprises leads to the positive results for the marketing. This study is conducted under the theory that the collaborative activations among companies based upon the trusted relationships built up for some period are the effective collaborative model for them aggressively to exchange their own administrative resources. And under the collaboration network, they can influence the flow of information and resources, procure and exchange such information and social capital, and build up the collaborative relationships, then it could be possible to receive various kinds of resources. That is, it supports the consumption that the collaboration through exchanging can reinforce the resources. (Prusak and Cohen;2001)

Table 1. Measurement Concepts (Independent Variable)

\begin{tabular}{|c|c|c|c|c|}
\hline \multicolumn{3}{|c|}{ Construct } & Measurement Item Description & References \\
\hline \multirow{9}{*}{$\begin{array}{c}\text { Information } \\
\text { Technology } \\
\text { Source of } \\
\text { resources }\end{array}$} & \multirow{3}{*}{$\begin{array}{l}\text { Resources, } \\
\text { technical } \\
\text { competence }\end{array}$} & T. IT 1 & $\begin{array}{c}\text { Technology in the } \\
\text { development Staffing levels }\end{array}$ & \multirow{3}{*}{$\begin{array}{c}\text { Boynton et al(1994) } \\
\text { Byrd and Turner(2000, } \\
\text { Byrd and Turner(2001) } \\
\text { Karimi et al(2001) } \\
\text { Melville et al(2004) }\end{array}$} \\
\hline & & T. IT 2 & $\begin{array}{l}\text { Equipment level of } \\
\text { research facilities }\end{array}$ & \\
\hline & & T. IT 3 & $\begin{array}{l}\text { Level of information } \\
\text { acquisition technology }\end{array}$ & \\
\hline & \multirow{6}{*}{$\begin{array}{c}\text { ( External } \\
\text { technology } \\
\text { sources) } \\
\text { Relationship } \\
\text { assets }\end{array}$} & R. A 1 & $\begin{array}{l}\text { Enterprise affiliated Institution } \\
\text { Mntenance of relation }\end{array}$ & \multirow{6}{*}{$\begin{array}{c}\text { Ford(1988) } \\
\text { Ford \& Thomas(1997) } \\
\text { Miller \& Morris(1999) } \\
\text { Kelly, Schaan \& } \\
\text { Joncas(2002) }\end{array}$} \\
\hline & & R. A 2 & $\begin{array}{c}\text { Academic-industrial cooperation } \\
\text { continue trade relation }\end{array}$ & \\
\hline & & R. A 3 & $\begin{array}{l}\text { government-contributed research } \\
\text { institute continue trade relation }\end{array}$ & \\
\hline & & R. A 4 & $\begin{array}{l}\text { government \& Support agencies } \\
\text { continue trade relation }\end{array}$ & \\
\hline & & R. A 5 & $\begin{array}{l}\text { Association \& Combination } \\
\text { continue trade relation }\end{array}$ & \\
\hline & & R. A 6 & $\begin{array}{c}\text { Technology Transfer Center continue } \\
\text { trade relation }\end{array}$ & \\
\hline
\end{tabular}


Table 2. Measurement Concepts(Dependent Variable Variable)

\begin{tabular}{|c|c|c|c|c|}
\hline \multicolumn{3}{|c|}{ Construct } & Measurement Item Description & References \\
\hline \multirow{9}{*}{$\begin{array}{c}\text { Ability to } \\
\text { manage } \\
\text { organization } \\
\text { al resources }\end{array}$} & \multirow{3}{*}{$\begin{array}{l}\text { Financial } \\
\text { resources } \\
\text { (Source of } \\
\text { internal } \\
\text { technology) }\end{array}$} & C. A 1 & External financing Degree of literacy & \multirow{3}{*}{$\begin{array}{c}\text { Mata et al(1995) } \\
\text { Powell and Dent - } \\
\text { Micallef(1997) } \\
\text { Bharadwaj(2000) } \\
\text { Burt(1992) Lin(2001) }\end{array}$} \\
\hline & & C. A 2 & possessed funds Degree of literacy & \\
\hline & & C. A 3 & $\begin{array}{c}\text { Financing from outer source } \\
\text { procurement capability }\end{array}$ & \\
\hline & \multirow{3}{*}{$\begin{array}{l}\text { Technical } \\
\text { capacity }\end{array}$} & $\mid \begin{array}{c}\text { T. O. C } \\
1\end{array}$ & Technique acquisition Alliance ability & \multirow{3}{*}{$\begin{array}{l}\text { Powell and Dent - } \\
\text { Micallef(1997) } \\
\text { Bharadwaj(2000) }\end{array}$} \\
\hline & & $\begin{array}{c}\text { T. O. C } \\
2\end{array}$ & $\begin{array}{l}\text { Technique acquisition alliance ability } \\
\text { Technical problem solving skill }\end{array}$ & \\
\hline & & T. O. C & Technical Staffing \& utilization ability & \\
\hline & \multirow{3}{*}{$\begin{array}{c}\text { Developmen } \\
\mathrm{t} \text { of new } \\
\text { technologies } \\
\text { performance }\end{array}$} & N. R. P 1 & $\begin{array}{l}\text { New merchandise in development } \\
\text { Improve production capacity }\end{array}$ & \multirow{3}{*}{$\begin{array}{l}\text { Sambamurthy and } \\
\text { Zmud(1997) } \\
\text { Bharadwaj(2000) } \\
\text { Ross et al.(1996) } \\
\text { Mata et al(1995) }\end{array}$} \\
\hline & & N. R. P 2 & $\begin{array}{l}\text { New merchandise in development } \\
\text { Accumulated experience }\end{array}$ & \\
\hline & & N. R. P 3 & $\begin{array}{l}\text { New product expand development } \\
\text { manpower }\end{array}$ & \\
\hline
\end{tabular}

\section{Measured Variables Data Collection and Measurement}

It can be called as the relational asset which is the factor with the asset value built under the relationships among enterprises. And relating to this relational asset, the term Market Asset is suggested, defining it as the intangible asset which would be obtained by the enterprises through the relationships from the participants in the system. In this study, the empirical analysis is conducted under the assumption that the role of relationship of the relational asset (trust, relational immersion, relationship pattern) comes to be effective on the operation and management ability of technique as well as the development outcome of new technology. For the sampling participated in the survey, 50 firms including mostly domestic IT related companies were selected. To secure the representativeness and professionalization, it has been conducted around CEO, executives, administrative manager, or head of the development having the knowledge of the company and administration.

For this study, the survey has been conducted after the preliminary survey for the 300 domestic IT firms. We limited responders to CEO or the people having the right of decisionmaking, and analyzed responds from 50 firms in totally 165 samplings. 
The survey was conducted from June 2012 to March 2013. It was done by using the questionnaire after selecting the sampling through the telephone call, Fax, e-mail, and so on.

\section{Analyzing the Research Model and Measurement Variable}

To investigate the research model for this study, we conducted the path analysis by using the structural equation application AMOS 16.0. To investigate the reliability and validity the conventional Cronbach alpha and confirmatory factor analysis were used. We analyzed the measurement variable based upon the Cronbach alpha, and also verified the conceptual validity and discriminant validity through the confirmatory factor analysis. As the results analyzed from Cronbach alpha, measurement variables wholly shows the reliability of about 0.7 Cronbach alpha. Also as all correlational value was meaningfully less than 1 , which was estimated from the confirmatory factor analysis model to verity the conceptual validity, so it can be concluded there would be discriminant validity. Even through the Fornell and Lackers(1981)'s validity verification way which is more strict way, it is also judged there is the conceptual validity because the AVEs(average variance extracted) are less than the multiple of correlational values.

Table 3. Estimate the Correlation between the Construct Validity

\begin{tabular}{|c|c|c|c|}
\hline \multicolumn{3}{|c|}{ Construct } & \multirow{2}{*}{\begin{tabular}{|c|} 
Correlation \\
0.238
\end{tabular}} \\
\hline Resources, technical competence & $\langle-->$ & $\begin{array}{c}\text { Financial resources } \\
\text { (Source of internal technology) }\end{array}$ & \\
\hline $\begin{array}{c}\text { Financial resources } \\
\text { (Source of internal technology) }\end{array}$ & $\langle-->$ & Technical capacity & 0.253 \\
\hline Technical capacity & $\langle-->$ & $\begin{array}{c}\text { Development of new technologies } \\
\text { performance }\end{array}$ & 0.465 \\
\hline $\begin{array}{c}\text { ( External technology sources) } \\
\text { Relationship capital }\end{array}$ & $\langle-->$ & $\begin{array}{c}\text { Development of new technologies } \\
\text { performance }\end{array}$ & 0.379 \\
\hline Resources, technical competence & $\langle-->$ & $\begin{array}{c}\text { ( External technology sources) } \\
\text { Relationship capital }\end{array}$ & 0.132 \\
\hline Resources, technical competence & $\langle-->$ & Technical capacity & -655 \\
\hline Resources, technical competence & $\langle-->$ & $\begin{array}{c}\text { Development of new technologies } \\
\text { performance }\end{array}$ & -139 \\
\hline $\begin{array}{c}\text { Financial resources } \\
\text { (Source of internal technology) }\end{array}$ & $\langle-->$ & $\begin{array}{c}\text { Development of new technologies } \\
\text { performance }\end{array}$ & 0.275 \\
\hline $\begin{array}{c}\text { (External technology sources) } \\
\text { Relationship assets }\end{array}$ & $\langle-->$ & $\begin{array}{c}\text { Financial resources } \\
\text { (Source of internal technology) }\end{array}$ & 0.277 \\
\hline $\begin{array}{c}\text { ( External technology sources) } \\
\text { Relationship assets }\end{array}$ & $<-->$ & Technical capacity & 0.299 \\
\hline
\end{tabular}


$x^{2}$ When looking at the result of the whole model fit, it showed appropriate index levels of the all suitability $=72.462$, GFI $=0.841$, AGFI=0.764, RMSEA=0.020, AIC $=140.462$, and CFI=0.992(Hair et.al 1995, Bagozi and Yi 1988). And the GFI=0.841, Absolute Fit Index, was slightly short, but other Incremental Fit Indexes including CFI=0.992, TLI(Tucker-Lewis index), IFI(Incremental Fit Index) were also fittable in the recommended index norms of suitability, so it is reasonable to explain the cause and effect of the research model.(Schumacker and Lomax;1996) Also according to the strict principle of RMSEA(Rootmean-square error of approximation), if it is ranged from 0.082 from 0.000 , it can be concluded reasonably. And in this study it showed very reasonable result with 0.020.(Byrne;1998, MacCallum et al.,;1996)

Table 4. Goodness of Fit Test of the Research Model

\begin{tabular}{|c|c|c|c|c|c|}
\hline Measures & $\begin{array}{c}\text { Recommended } \\
\text { Level }\end{array}$ & $\begin{array}{c}\text { Research } \\
\text { Model }\end{array}$ & Measures & $\begin{array}{c}\text { Recommended } \\
\text { Level }\end{array}$ & $\begin{array}{c}\text { Research } \\
\text { Model }\end{array}$ \\
\hline$x^{2}(\mathrm{DF})$ & - & 72.462 & AIC & - & 140.462 \\
\hline GFI & Above 0.9 & 0.841 & CFI & Above 0.9 & 0.992 \\
\hline RMSEA & $90 \%$ C.I & 0.020 & AGFI & Above 0.9 & 0.764 \\
\hline TLI & Above 0.9 & 0.990 & IFI & Above 0.9 & 0.993 \\
\hline CMIN/DF & $x^{2} / d f 3$ & 1.021 & PGFI & Above 0.5 & 0.568 \\
\hline RMR & Below 0.10 & 0.082 & NFI & Below 0.10 & 0.743 \\
\hline
\end{tabular}

\section{Research Hypothesis and Research Finding}

From the hypothesis [1] "the relational asset activation of intermediate IT organizations as the outer technique oriented relational assets would be necessary to solve the problem of lack of technical skills" $(\beta=0.11)$, it can be understood that the firms still prefer to develop by itself. Though they are at the end of the development such as in-house human resource, facility, and information, because of their low recognitions for the joint development and technology transfer, they'd like to decide to solve problems by itself such as securing the original technology, outer funds raising, and keeping the capital rather than cooperating and procuring from the government owned institutions, collages, and other firms. However, like [Hypothesis 2], when the enterprises can utilize the activation as its financial resources through the activation of relational asset, it was found that they could secure it. $(\beta=0.49)$ Like this, the activation as its financial resources played a definitive variation to solve the company's problem of limited technical ability. Therefore, in this study it showed that those companies could get the forces by building up the technical ability (Assumption 6: $\beta=0.25$ ) and the outcome of the development of new technology (Assumption 7; $\beta=0.21$ ) when the financial resources are prepared enough as the source of in-house technology(Assumption 2; $\beta=0.49$ ) through proceeding the role of relational assets. 
So it showed the critical role of the leading variable for the activations of intermediate organizations through the relative cooperation of government owned institutions, government operated research center, companies(including the companied owned research center), collage(including industry-academic cooperation), technology transition institution(technology transferring). It was also concluded that the role lead the companies to get the technology, the ability of strategic alliance, and the ability of problem solving, and also could be the factor for securing the engineers and operation ability.(Assumption 4; $\beta=0.38$ ) It was also found that the companies could accommodate the experience and the productive ability for the development of new product, as well as getting the human resources. (Assumption 7; $\beta=0.21$ ) So, there did not directly occurred any forces for the development of the new technology by the activation of relative asset, while the relative asset influenced on the ability of technology. Therefore, only when the activation of relative asset and technical ability are ready, it can impact on the procedure of developing new technology. Without solving this problem, it was found that they couldn't get any direct effect from the development of new technology.(Assumption 5; $\beta=0.02$ ) The in-house financial resources also lead to build up the technical ability(Assumption $6 ; \beta=0.25$ ) and also influence on the outcome of development(Assumption 7; $\beta=0.21$ ), and at the same time it didn't influence on the development procedure directly.(Assumption 5; $\beta=0.02$ ) Therefore enterprises need to proceed the relational activations of the intermediate organizations in advance, and also build up the strategic partnerships to lead the outcome of development procedures. Also when they develop their own skills in their own research centers, then it is going to be affordable to get the outcome of new products along with the technical levels. So, enterprises need to build up the concrete and strategic decision making instead of building up the technical ability such as partnership, solving problems, utilizing human resources.

Table 5. Hypotheses Significance Test Result

\begin{tabular}{|c|c|c|c|c|c|}
\hline \multicolumn{2}{|r|}{ Hypotheses Path } & \multirow{2}{*}{$\begin{array}{c}\text { Path } \\
\text { coefficients } \\
0.11\end{array}$} & \multirow{2}{*}{$\begin{array}{c}\text { S.E } \\
0.147\end{array}$} & \multirow{2}{*}{$\begin{array}{c}\text { C.R } \\
0.735\end{array}$} & \multirow{2}{*}{$\begin{array}{l}\text { Research } \\
\text { Result } \\
\text { reject }\end{array}$} \\
\hline $\mathrm{H} 1$ & $\begin{array}{c}\text { Resources, technical competence } \rightarrow \\
\text { ( External technology sources) Relationship Assets }\end{array}$ & & & & \\
\hline $\mathrm{H} 2$ & $\begin{array}{l}\text { ( External technology sources) } \rightarrow \text { Relationship } \\
\qquad \text { Capital } \\
\text { Financial resources (Source of internal technology) }\end{array}$ & 0.49 & 0.306 & 1.591 & accept \\
\hline H3 & $\begin{aligned} \text { Resources, technical competence } & \rightarrow \\
\text { Technological capabilities } & \end{aligned}$ & -0.76 & 0.198 & -3.835 & accept \\
\hline $\mathrm{H} 4$ & $\begin{array}{c}\text { ( External technology sources) Relationship Assets } \\
\rightarrow \\
\text { Technological Capabilities }\end{array}$ & 0.38 & 0.209 & 1.803 & accept \\
\hline H5 & ( External technology sources) Relationship Assets & 0.02 & 0.054 & 0.391 & reject \\
\hline
\end{tabular}




\begin{tabular}{|c|c|c|c|c|c|}
\hline & $\begin{array}{c}\rightarrow \\
\text { Development of new technologies performance }\end{array}$ & & & & \\
\hline $\mathrm{H} 6$ & $\begin{array}{l}\text { Financial resources (Source of internal technology) } \\
\qquad \rightarrow \\
\text { Technological capabilities }\end{array}$ & 0.25 & 0.106 & 2.312 & accept \\
\hline $\mathrm{H} 7$ & $\begin{array}{c}\text { Technological capabilities } \rightarrow \\
\text { Development of new technologies performance }\end{array}$ & 0.21 & 0.172 & 1.232 & accept \\
\hline $\mathrm{H} 8$ & $\begin{array}{l}\text { Financial resources (Source of internal technology) } \\
\qquad \rightarrow \\
\text { Development of new technologies performance }\end{array}$ & -0.08 & 0.073 & -1.135 & reject \\
\hline
\end{tabular}

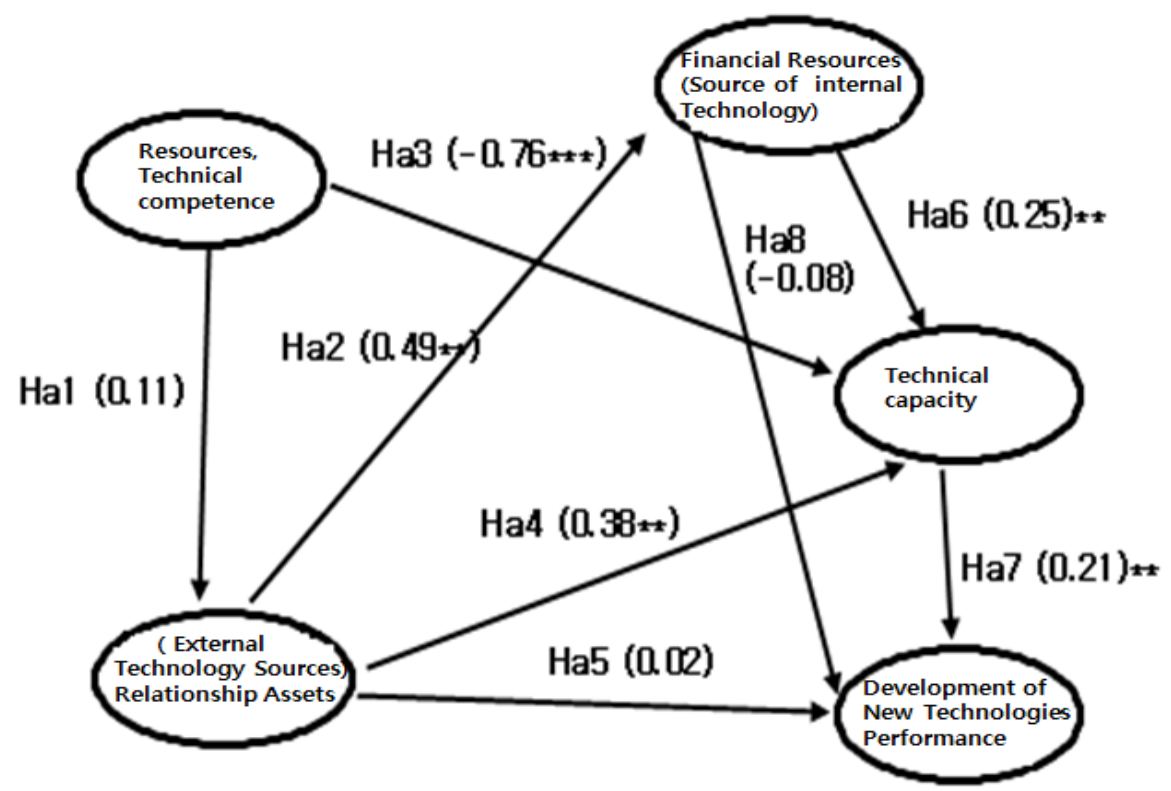

Figure 1. Research Model and Path Coefficients

As the above outcomes from this study, it can be understood the role of collaborative relational assets of government supported organizations $\left(\beta=0.846,{ }^{* * *}\right)$ including government funded organizations $(\beta=0.732,0.001)$ is important. This result supports the hypothesis that the intermediate organizations are possible to play a role of such relationships as managing the information and flow of resources because they are positioned amid the flow of resources and information, and such intermediate groups can enhance the social capitals higher since they can obtain various and fresh information and resources from the network composed of many intermediate groups faster than others not engaged in the network.(Burt;1992, Lin;2001).

\section{Conclusion}


In this study, it tried to employ the social network theory from the viewpoint of Resource Dependence Perspective to utilize IT and active the intermediate group for the purpose of securing the ability of resource. To enhance the ability of intermediate groups, it was suggested the importance of collaborative asset activation. Therefore, it is concluded that they do their best efforts to use the network of knowledge and information as to use outer resources and in-house knowledge as the way of preparing for the global technology competition and recession of R\&D productivity.

In such areas as HT(high technology industry), IT, and BT, there is possibly brought forth the critical point to turn the in-house and outer abilities into company's own assets. By this reason, companies would utilize the scale economy and economy of scope to get the specialized technology through the R\&D collaborative network. Especially in the verge of knowledge society, the competitive focus strategy for the technical development is to be recognized importantly because it can be strategic investment to secure the qualified human resources having a high technical knowledge and to develop the qualified human resources.

For the most desirable collaborative relationship to enhance the technical ability, it is necessary to enhance the productivity, develop the human resource, and prepare for the competitive environment for the accumulation of the new product development through the strategic choice and supportive cooperation of outer circumstances(product, technique, market) and harmonized relation pattern.

In the IT world where the accumulation of technology is important, the enhancement of the intermediate groups' activations as well as the government supports causes the strategic direction with competition and collaboration built to secure the public character for the construction of collaborative interests and trust in the public sector, and by the meaning of chance, and leads the ability of partnership to be built. There is a limitation not to suggest the way of strategic partnership in detail in this study. It is expected that other studies would suggest the enterprise's strategic decision making.

\section{Acknowledgements}

Project supported by the National Natural Science Foundation of China (Grant No. 61262090)

\section{References}

[1] R. P. Bagozzi and Y. Yi, "On the Evaluation of Structural Equation Models," Journal of Academy of Marketing Science, vol. 16, no. 1, (1988), pp. 74-97.

[2] S. E. Beatty, P. Homer and L. R. Kahle, "The involvement committment model: theory and implication", Journal of Business Research, vol. 16, (1988), pp. 149-167.

[3] A. Boynton, R. W. Zmud and G. C. Jacobs, "The influence of IT management practice on IT use in large organizations", MIS Quarterly, (1994), pp. 299-318.

[4] A. S. Bharadwaj, "A Resource-based Perspective on Information Technology Capability and Firm Performance: An Empirical Investigation”, MIS Quarterly, vol. 24, no. 1, (2000), pp. 169-196.

[5] A. Boynton, R. W. Zmud and G. C. Jacobs, "The influence of IT management practice on IT use in large organizations”, MIS Quarterly, (1994), pp. 299-318.

[6] R. S. Burt, "Structural Holes: The Social Structure of Competition", Cambridge, Harvard Business Press, (1992).

[7] B. M. Byme, "Structural Equation Modeling With LISREL, PRELIS, and SIMPLIS; Basic Concepts, Applications, and Programming", Mahwah, NJ; Lawrence Erlbaum, (1998), pp. 112.

[8] T. A. Byrd and Turner, D. E, "Measuring the flexibility of Information technology infrastructure:exploratory analysis of a construct", Journal of Management Information Systems, vol. 17, no. 1, (2000), pp. 167-208.

[9] T. A. Byrd and D. E. Turner, "An exploratory analysis of the value of the skills of IT personnel: their relationship to IS infrastructure and competitive advantage", Decision Sciences, vol. 32, no. 1, (2001), pp. 21-54. 
[10] T. G. Cummings \& C. G. Worley, Organization Developmentand Change(8thed).South Westem: Thomson, (2004).

[11] A. J. Elliot and M. A. Church, "Hierarchical Model of Approach\& Avoidance Achievement Motivation", Journal of Personality and Social Psychology, vol. 72, no. 1, (1997), pp. 218-232.

[12] C. Fornell and D. Larcker, "Evaluating structural equation models with unobservable variables \& measurement error", Journal of Marketing Research, vol. 18, (1981), pp. 39-50.

[13] D. Ford, "Developing your technology strategy", Long Range Planning, vol. 21, (1988), pp. 85-95.

[14] D. Ford and R. Thomas, "Technology strategy in networks", International Journal of Technology Management, vol. 14, (1997), pp. 596-612.

[15] W. French, C. H. Bell and R. Zawacki, Organizational Developmentand Transformation.MacGraw-Hill, (2003).

[16] J. F. Hair, R. E. Anderson, R. L. Tatham and W. C. Black, "Multivariate Data Analysis with Readings", (4th ed.). Englewood Cliffs, NJ: Prentice-Hall, (1995).

[17] J. Karimi, T. M. Somers and Y. P. Gupta, "Impact of information technology management practices on customer service", Journal of Management Information Systems, vol. 17, no. 4, (2001), pp. 125-158.

[18] M. J. Kelly, J.-L. Schaan and H. Joncas, "Managing alliance relationships: Key challenges in the early stages of collaboration”, R\&D Management, vol. 32, (2002), pp. 11-22.

[19] K.-H. Han, "The Moderating Effects of Self-Efficacy on the Relationships between the Employees' Dispositional Traits and Job Burnout", Journal of the Korean Academic Society of Business Administration, vol. 18, no. 2, (2005), pp. 531-555.

[20] N. Lin, "Social Capital: A Theory of Social Structure and Action", Cambridge University Press, (2001).

[21] R. C. MacCallum, M. W. Browne and H. M. Sugawara, "Power Analysis and Determination of Sample Size for Covariance Structure Modeling”, Psychological Methods, vol. 1, (1996), pp. 130-149.

[22] F. Mata, W. Fuerst and J. Barney, "Information Technology and Sustained Competitive Advantage: A Resource-based Analysis", MIS Quarterly, vol. 19, no. 4, (1995), pp. 487-505.

[23] N. Melville, K. Kraemer and V. Gurbaxani, "Review: Information technology and organizational performation technology and organizational performance: an integrative model of IT business value", MIS Quarterly, vol. 28, no. 2, (2004), pp. 283-322.

[24] W. L. Miller and L. Morris, Fourth Generation R\&D. John Wiley \& Sons, (1999).

[25] T. C. Powell and A. Dent-Micallef, "Information technology as competitive advantage: the role of human, business, and technology resources", Strategic Management Journal, vol. 18, no. 5, (1997), pp. 375-405.

[26] L. Prusak and D. Cohen, "How to Invest in Social Capital", Harvard Business Review, (2001) June, pp. 8693.

[27] J. W. Ross, C. M. Beath and D. L. Goodhue, "Develop Long-term Competitiveness through IT Assets", Sloan Management Rewiew, vol. 38, no. 1, (1996), pp. 31-45.

[28] V. Sambamurthy and R. W. Zmud, "At the heart of success: organizaionwide management competencies", Steps to the future: fresh thinking on the management of IT-based organizational transformation, C. Sauer and P.W. Yetton(eds.), Jossey-Bass, San Francisco, (1997), pp. 143-163.

[29] R. E. Schumacker and R. G. Lomax, “A Beginners Guide to Structural Equation Modeling”, Mahwah, NJ: Lawrence Erlbaum, (1996).

\section{Authors}

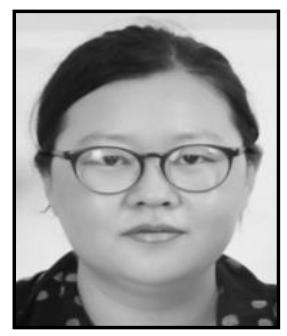

LiHua Cui received the Ph.D. degree from KookMin University, major in Financial Management in 2008. She is currently a professor of Dept. of Financial Management at Yanbian University in China. She research interests are in the areas of business finance, value assessment, merger and acquisition, Engaged in financial analysis. 


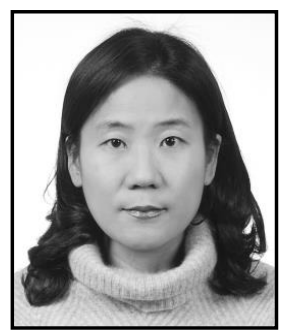

Hye Jeong Kim received the Ph.D. degree from KookMin University, major in Business Administration in 2006. She is currently a professor of Dept. of Operations Management at Kyonggi University in Korea. She is also a Principal Researcher at Institute, Human Resource Development Institute of Korea. She research interests are in the areas of Technology and Engineering, Production /Operations Management, Quality Management.

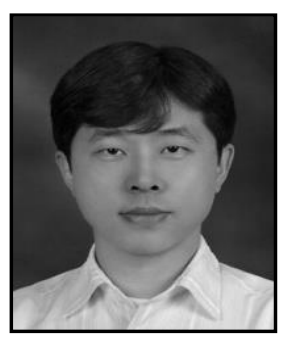

De Li received the Ph.D. degree from Sangmyung University, major in computer science in 2005. He is currently a professor of Dept. of Computer Science at Yanbian University in China. His research interests are in the areas of Technology and Engineering, value assessment, financial analysis, copyright protection, digital rights management. 